\title{
The efficacy of potassium sorbate-coated packaging to control postharvest gray mold in raspberries, blackberries, and blueberries
}

Article

Accepted Version

Junqueira-Gonçalves, M. P., Alarcon, É. and Niranjan, K. (2016) The efficacy of potassium sorbate-coated packaging to control postharvest gray mold in raspberries, blackberries, and blueberries. Postharvest Biology and Technology, 111. pp. 205-208. ISSN 0925-5214 doi:

https://doi.org/10.1016/j.postharvbio.2015.09.014 Available at https://centaur.reading.ac.uk/43637/

It is advisable to refer to the publisher's version if you intend to cite from the work. See Guidance on citing.

To link to this article DOI: http://dx.doi.org/10.1016/j.postharvbio.2015.09.014

Publisher: Elsevier

All outputs in CentAUR are protected by Intellectual Property Rights law, including copyright law. Copyright and IPR is retained by the creators or other copyright holders. Terms and conditions for use of this material are defined in the End User Agreement. 


\section{www.reading.ac.uk/centaur}

\section{CentAUR}

Central Archive at the University of Reading

Reading's research outputs online 


\section{The efficacy of potassium sorbate-coated packaging to control postharvest gray mold} in raspberries, blackberries, and blueberries

Maria Paula Junqueira-Gonçalves ${ }^{1 *}$, Érica Alarcon $^{2}$, Keshavan Niranjan $^{3}$

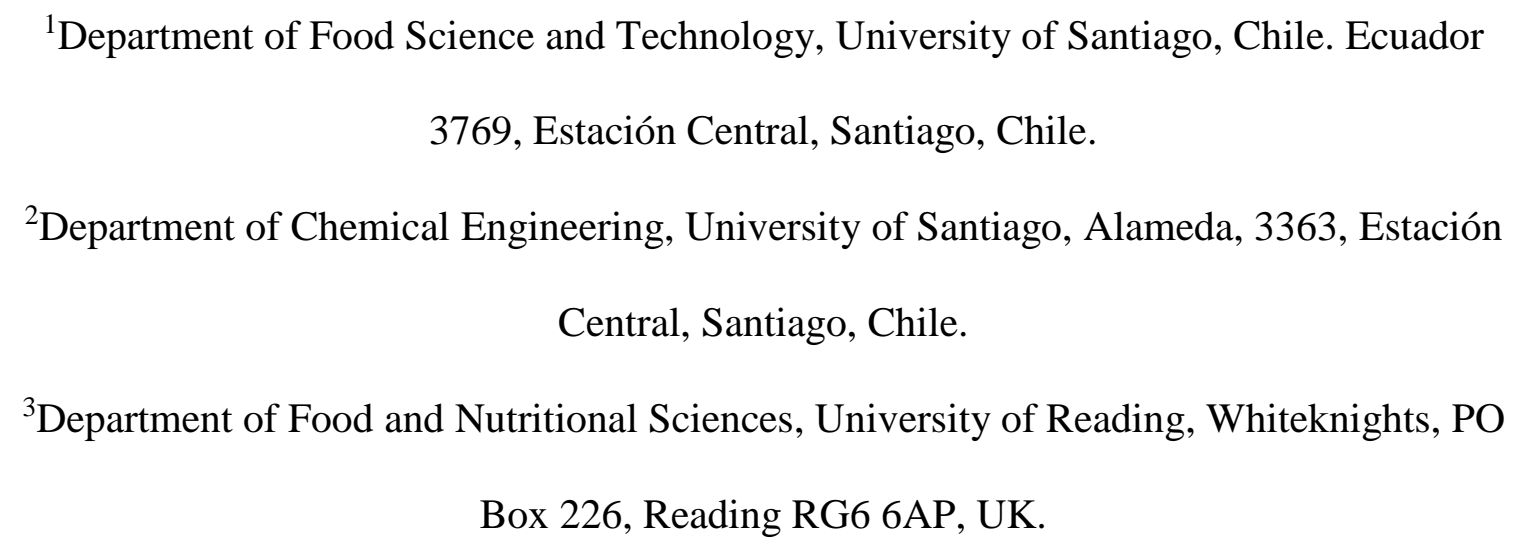

\section{Abstract}

The aim of this work is to build on the success of in vitro studies of an active packaging, produced by coating the surface of post-consumer recycled polyethylene terephthalate (PCRPET) package with an aqueous silicone solution $(2 \%, \mathrm{v} / \mathrm{v})$ containing an antifungal agent (potassium sorbate, KS). Antifungal efficacy was evaluated, in vivo, during the storage of raspberries, blackberries and blueberries by examining their shelf life extension. The packaging effectively delayed the growth of Botrytis by extending its lag-phase, which, in turn, extended the shelf life of the berries by up to $3 \mathrm{~d}$. Among the three berries tested, the packaging proved to be more advantageous in the case of raspberries, due to their physiological characteristics and shorter shelf life. Based on sensory panel evaluations, it was shown that the coating, containing KS, did not influence the packaging appearance and transparency, and the fruit did not suffer from any off-flavor development.

${ }^{*}$ Corresponding autor: Tel: +56-2-27184519; Fax: +56-2-27764796

E-mail: mpaula.junqueira@usach.cl (M.P. Junqueira-Gonçalves) 
22 Keywords: Active packaging; Botrytis cinerea; fresh berries; shelf-life; potassium sorbate.

23

24

25

26

27

28

29

30

31

32

33

34

35

36

37

\section{Introduction}

There is a growing and impressive evidence base for the health benefits of fresh berry consumption (Tulipani et al., 2008). Berries are a rich source of a wide variety of nonnutritive and bioactive compounds such as flavonoids, phenolics, anthocyanins, phenolic acidsas well as nutritive compounds such as sugars, essential oils, carotenoids, vitamins, and minerals (Nile and Park, 2014). However, a common problem with berries is their high perishability due to rapid ripening and senescence, which hampers storage and marketing (Han et al., 2004). The postharvest life of berries is also determined by their susceptibility to water loss, softening, mechanical injuries, but primarily by the postharvest diseases of gray mold and Rhizopus rot (Reddy et al., 2000; Perkins-Veazie et al., 2008).

Gray mold, caused by $B$. cinerea, is the most important postharvest disease in berries, and has a considerably adverse economic impact. This mold is responsible for significant loss, both before and after harvest, and is a major obstacle to long-distance transport and storage because it can grow at temperatures as low as $-0.5^{\circ} \mathrm{C}$ and spreads rapidly by means of aerial mycelium among the berries (Crisosto and Mitchell, 2002).

Polyethylene terephthalate (PET) is the most commonly used packaging material, worldwide, for marketing berries. In order to minimize polymer waste the use of recycled PET is increasing (Dimitrov et al., 2013).

Junqueira-Gonçalves et al. (2014) described the development of an active packaging designed with post-consumer recycled polyethylene terephthalate (PCRPET) and incorporated potassium sorbate $(\mathrm{KS})$ as an antifungal agent to fight $B$. cinerea. The mechanical, thermal and optical properties of the packaging material were evaluated and its 
45 efficacy against $B$. cinerea was demonstrated by employing a novel methodology that 46 mimics actual food contact conditions.

47 The aim of this work was to confirm the promise indicated in the earlier in vitro studies 48 and evaluate the antifungal efficacy of the potassium sorbate-coated packaging, in vivo, 49 during the storage of raspberries, blackberries and blueberries.

\section{Material and method}

\subsection{Materials}

The polymer used in this study was PCRPET (Typack S.A., Chile), approved by the FDA (Food and Drug Administration) to be in contact with fresh fruits coated with KS (Prinal, Chile) as the antifungal agent. The raspberries, blackberries and blueberries employed were standard export quality, from different origins (Chile, Spain and Mexico) and harvested in different years (2012 and/or 2013). These were delivered by two marketing companies, one in Chile (Vital Berry Marketing S.A.) and another in England (Berry World).

\subsection{Packaging preparation}

The incorporation of potassium sorbate on the surface of the PCRPET was carried out during sheet manufacture by passing it through a bath containing an aqueous silicone solution $(2 \%, \mathrm{v} / \mathrm{v})$ to which $\mathrm{KS}$ has been added at a concentration of $20 \%(\mathrm{w} / \mathrm{v})$. Coating PET with silicone is standard practice in the manufacture of PET packaging, which prevents individual packaging pieces from adhering on high speed manufacturing lines. The addition of $\mathrm{KS}$ to the silicone solution imparted antifungal properties to the PET surface, as described by Junqueira-Gonçalves et al. (2014), with an active percentage of $0.005 \%$. The sheet was converted to clamshells by thermoforming (John Brown Inc., USA). Some 
68 clamshells were also produced from sheets that were only coated with silicone but not KS,

69 and these constituted the control samples.

70

71

72

73

74 79 in Table 1.

80

81

82

83

84

85

86

87

88

89

90

\subsection{Assessment of the shelf life of berries}

The fruit (125g per package) were carefully transferred to the control and active clamshells, and stored in chambers maintained at 0,5 and $10^{\circ} \mathrm{C}$, simulating temperatures employed during transportation and retailing. Seven replicate clamshells were used for each condition (active and control) and the test was repeated twice.

The efficacy of the potassium sorbate-coated packaging on the berries shelf life was evaluated by the incidence of gray mold-infected berries per clamshell, visually or with the help of magnifying glasses. This test was carried out on the day the fruit arrived at the laboratories after harvest. The specific conditions employed for each fruit study are shown

\subsection{Sensory evaluation}

A sensory assessment was carried out by a trained panel (who were familiar with the major sensory attributes of good quality berries: taste, aroma, texture and colour of the samples), consisting of 8 women and 3 men, using an unstructured 15-point hedonic scale, where 0 represents the worst, and 15 the best condition, meaning very good or very intense, in order to evaluate the packaging appearance and also its influence on fruit aroma and flavor. The raspberries and blueberries were stored at $5^{\circ} \mathrm{C}$ for 4 and $18 \mathrm{~d}$, respectively. These fruits originated from the south of Chile and the storage studies commenced a day after harvest (December, 2012). The samples (125g) were held at ambient temperature (around $25^{\circ} \mathrm{C}$ ) $30 \mathrm{~min}$ before the test, coded with 3-digit random numbers, and served simultaneously under normal laboratory light. 


\subsection{Statistical analysis}

Experimental values were statistically analyzed by one-way analysis of variance (ANOVA) employing Statgraphics 5.1 software. Differences between pairs of means were assessed on the basis of confidence intervals using the Tukey test. The least significance difference was $\mathrm{P} \leq 0.05$.

\section{Results and Discussion}

\subsection{Assessment of the shelf life of berries}

- Raspberries

The raspberries from the south of Chile were harvested in December 2012 and arrived in Santiago by truck, one day after harvesting. The temperature of transport was less than $5^{\circ} \mathrm{C}$. These fruit were stored at $10^{\circ} \mathrm{C}$ for $11 \mathrm{~d}$. The results of the packaging efficacy are shown in Figure 1.

The raspberries from Spain were harvested in March 2013 and arrived in England by truck, $3 \mathrm{~d}$ after harvesting. The temperature of transport was less than $5^{\circ} \mathrm{C}$. These fruit were stored at $5^{\circ} \mathrm{C}$ for $7 \mathrm{~d}$. The results of the packaging efficacy are shown in Figure 2.

In both tests a significant difference $(\mathrm{P}<0.05)$ between the control and the potassium sorbate-coated packaging was observed. An extension in the shelf life of the raspberries of 2 or $3 \mathrm{~d}$ were observed, especially in the case of the Chilean fruit because they were in contact with the active packaging a few days sooner after harvesting when compared to the Spanish fruit.
- Blackberries 
113 by air freight, $1 \mathrm{~d}$ after harvesting. The temperature of transport was $10^{\circ} \mathrm{C}$. These fruit were 114 stored at $5^{\circ} \mathrm{C}$ for $23 \mathrm{~d}$. The results of the packaging efficacy are shown in Figure 3.

115 In the case of blackberries too, a significant difference $(\mathrm{P}<0.05)$ between the control 116 and the potassium sorbate-coated packaging was also observed and an extension in the fruit 117 shelf life of 1 or $2 \mathrm{~d}$ was clear.

The blueberries harvested in December 2012 were from the south of Chile, from two different producers (Region of Los Lagos and Region of Araucania) and arrived in Santiago by truck, $1 \mathrm{~d}$ after harvesting. The temperature of transport was less than $5^{\circ} \mathrm{C}$. These fruit 122 were stored at 0 and $10^{\circ} \mathrm{C}$ for $28 \mathrm{~d}$.

The fruit originally from the Region of Los Lagos had a low percentage of gray mold 124 during the entire storage time at 0 and $10^{\circ} \mathrm{C}$; therefore it was not possible to evaluate the 125 difference between the packaging systems.

126 The fruit originally from the Region of Araucania also had a low percentage of gray 127 mold at $0^{\circ} \mathrm{C}$, but at $10^{\circ} \mathrm{C}$ it was possible to observe the effect of the packaging on mold 128 growth (Fig. 4).

129 In this trial it was possible to observe a significant difference $(\mathrm{P}<0.05)$ between the 130 potassium sorbate-coated packaging and the control after $21 \mathrm{~d}$ of storage.

131 The blueberries harvested in February 2013 were from the south of Chile (Region of 132 Bio Bio) and arrived in Santiago by truck, one day after harvesting. The temperature did 133 not exceed $5^{\circ} \mathrm{C}$ during transport, and the fruit were stored at $0^{\circ} \mathrm{C}$ for $49 \mathrm{~d}$. 
135 was not possible to quantify statistically, any differences between the packaging systems.

136 The samples were then divided into two parts and stored for $4 \mathrm{~d}$ under conditions that were

137 highly favorable for mold development: one part was stored at ambient temperature $138\left(24 \pm 1^{\circ} \mathrm{C}, 60 \% \mathrm{RH}\right)$ and the other part was stored in a humid chamber $\left(95 \% \mathrm{RH}, 20 \pm 1^{\circ} \mathrm{C}\right)$.

139 Figure 5 depicts the results, which show that under both storage conditions gray mold 140 incidence in the potassium sorbate-coated packaging was marginally lower, although 141 statistically no significant differences $(\mathrm{P}>0.05)$ were found.

142 Antimicrobial active packaging is one of the most promising active food packaging 143 concepts for extending the shelf life of fresh produce. This technology can prevent 144 microbial growth on the product by means of interactions between the food and the 145 packaging materials (Almenar et al., 2008). In the case of the packaging used in this work 146 the additive is already available on the packaging surface and its action starts as soon as the 147 fruits are in contact with the packaging, and it is not necessary to wait for the antifungal 148 migration through the packaging structure.

149 Several research studies have shown that potassium sorbate can be used and is an 150 effective remedy for the postharvest treatment against Penicilliumdigitatum (Smilanick et 151 al., 2008), Helminthosporiumsolani (Hervieuxet al., 2002), Fusariumsambucinum 152 (Mecteauet al., 2002), Fusariumsolani (El-Moglyet al., 2004), Moniliafructigena, 153 Phytophthoracapsici, Rhizoctoniasolani (Nikolov and Ganchev, 2011) and B. cinerea 154 (Nikolov and Ganchev, 2011).

155 Sofos (1989) reviewed antifungal activity of sorbates, and reported that a concentration 156 of $0.05-0.15 \%$ was needed to inhibit the growth of many fungi in foods, and this 157 concentration was influenced by $\mathrm{pH}$ and temperature. 
159 observed on the growth of $B$. cinerea, between 0.07 and $0.10 \%(\mathrm{w} / \mathrm{v})$, when the initial 160 concentration of $B$. cinerea is $10^{3}$ conidia/mL, and a specific migration concentration of $\mathrm{KS}$ 161 from the active packaging was found to be $46.37 \pm 2.39 \mathrm{mg} / \mathrm{kg}$, which is within the 162 compliance threshold for food legislation (60 mg/kg, Commission Regulation EU10/2011).

163 Thus, according to these results, the active concentration $(46.37+2.39 \mathrm{mg} / \mathrm{kg})$ is between 5 164 and 20 times lower than the minimum inhibitory concentration stated above $(0.05-0.15 \%)$. 165 This suggests an influence of KS on the lag-phase for the growth of Botrytis, i.e. KS acts 166 by delaying mold growth, but not inhibiting growth completely. The present study found 167 the fruit shelf life increased by up to $3 \mathrm{~d}$, and this is more important in the case of 168 raspberries due to their shorter shelf life.

169 Leistner (2000) hypothesizes that antimicrobial agents as well as all the measures taken 170 to preserve food products tend to temporarily or permanently disturb the homeostasis, i.e. 171 internal cell stability of the living organisms. When this occurs, the organism uses up all its 172 energy to overcome this disruption so it cannot multiply, remaining in the lag-phase or even 173 dying, before homeostasis is re-established.

174 Among the three berries tested, a superior efficacy of the potassium sorbate-coated 175 packaging was observed with raspberries, followed by blackberries and then blueberries. 176 Due to the fine skin and texture of the raspberries, it is easier to interact with the antifungal 177 agent on the packaging surface. The blueberries are covered in a natural protective coating 178 of powdery epicuticular wax, colloquially known as the "bloom" that makes the interaction 179 between the fruit and the potassium sorbate more difficult. 
182 in control and the active packaging, which means that the packaging transparency was not 183 affected by the KS addition on its surface, and also no aroma or flavor alterations were

184 found due to the KS addition (Table 2). The panellist group evaluated as satisfactory to 185 good, the aroma and flavour of the raspberries and blueberries without a significant 186 difference between the packaging types.

\section{4. Conclusions}

188 The potassium sorbate-coated packaging evaluated in this work proved to be efficient 189 in delaying the growth of Botrytis in the tested berries, by extending the mold lag-phase, 190 and thereby extending the shelf life by up to $3 \mathrm{~d}$.

191 The active packaging was effective at different storage temperatures.

192 Due to the physiological characteristics of raspberries and its shorter shelf life, these 193 fruit benefits more from the use of potassium sorbate-coated active packaging than 194 blackberries and blueberries, although the packaging is just as effective.

195 According to the sensory evaluation, the addition of KS did not affect the packaging 196 appearance, transparency, and the fruits did not suffer from off flavor development.

\section{Acknowledgements}

198 The authors would like to thank the Chilean Government for supporting this work 199 through Project FONDEF D08I-1028.

\section{References}


201 Almenar, E., Catala, R., Hernandez-Munoz, P., Gavara, R. 2009. Optimization of an active 202 package for wild strawberries based on the release of 2-nonanone. LWT Food Sci. 203 Technol. 42, (2) 587-593.

204 Commission Regulation (EU) No 10/2011of 14 January 2011on Plastic materials and 205 articles intended to come into contact with food. Official Journal of the European 206 Union, 15/01/2011.

207 Crisosto, C.H., Mitchell, F.G. 2002. Postharvest handling systems: small fruits. 208 Tablegrapes. In: Kader, A. (Ed.), Postharvest Technology of Horticulture Crops. Uni209 versity of California, Agriculture and Natural Resources, Oakland, p. 357-363.

210 El-Mougly, S. N., Abd-El-kareem, F., El-Gamal, N., Fatooh,Y. 2004. Application of 211 fungicidesalternatives for controlling cowpea root rot disease under greenhouse and 212 field conditions. Egypt. J.Phytopathol., 32: 23-35.

213 Han, C., Zhao, Y., Leonard, S.W., Traber, M.G. 2004. Edible coatings to 214 improvestorability and enhance nutritional value of fresh and frozen strawberries (Fra215 garia $\times$ ananassa) and raspberries (Rubusideaus). Postharvest Biol. Technol 33, 67-78.

216 Hervieux, V., Yaganza,E.,Arul, J. and Tweddell,R. 2002. Effect of organic and inorganic 217 saltson the development of Helminthosporiumsolani, the causal agent of potato silver 218

Junqueira-Goncalves, M. P., Alarcón, E., Niranjan, K. 2014. Post-consumer recycled PET scurf. Plant Disease 86 (9), 1014-1018. packaging for fresh berries:A comparative study between incorporating an antifungal agent superficially and into the main body of the packaging. Food Bioprocess Technol. 7, 2610-2617. 
223 Leistner, L. 2000. Basic aspects of food preservation by hurdle technology, International 224 Journal of Food Microbiology, 55, 181-186.

225 Nile, S. H., Park,S. W. 2014. Edible berries: Bioactive components and their effect on 226 human health. Nutrition, 30, 134-144.

227 Nikolov, A., Ganchev, D. 2011. In vitro antifungal examination of potassium sorbate 228 towards some phytopathogens. Bulg. J. Agric. Sci., 17: 191-194

Perkins-Veazie, P., Collins, J.K., Howard, L. 2008. Blueberry fruit response to postharvest application of ultraviolet radiation. Postharvest Biol. Technol. 47,280-285.

231 Reddy, M.V.B., Belkacemi, K., Corcuff, R., Castaigne, F., Arul, J. 2000. Effect of pre232 harvest chitosan sprays on post-harvest infection by Botrytis cinerea and quality of 233 strawberry fruit. Postharvest Biol. Technol. 20, 39-51.

234 Smilanick, L., Mansour,M., Mlikota,F., Sorenson, D. 2008. Control of citrus postharvest 235 greenmold and sour rot by potassium sorbate combined with heat and fungicides. 236 Postharvest Biol. Technol.,47:226-238.

237 Sofos, J.N. 1989.Sorbate Food Preservatives, CRC Press, Boca Raton, FL.

238 Tulipani S., Mezzetti B., Capocasa F., Bompadre S., Beekwilder J., de Vos C.H.R., 239 Capanoglu E., Bovy A., Battino M. 2008. Antioxidants, phenolic compounds, and 240 nutritional quality of different strawberry genotypes. J Agric Food Chem.56(3):696$241 \quad 704$. 